\title{
DPF1 wt Allele
}

National Cancer Institute

\section{Source}

National Cancer Institute. DPF1 wt Allele. NCI Thesaurus. Code C157305.

Human DPF1 wild-type allele is located in the vicinity of $19 q 13.2$ and is approximately 19 $\mathrm{kb}$ in length. This allele, which encodes zinc fing er protein neuro- $\mathrm{d} 4$, plays a role in neuronal cell survival and dendrite growth. 